\title{
A Literary Voyage into the Unconscious: A Philosophical Approach to the Psychological Novel in Woolf's Mrs. Dalloway (1925)
}

\author{
Nariman LARBI \\ Abdelhamid Ibn Badis University of Mostaganem \\ Algeria
}

\begin{abstract}
:
The present paper attempts to reawaken the avant-gardism of the literary Stream of Consciousness; a twentieth-century psychological concept that has been accommodated into fictional exertion through the Interior Monologue. The first practitioners of this technique and mode of narrative reportedness are Virginia Woolf, Dorothy Richardson, and James Joyce, all of whom are modernist fictional writers who engaged with what previous novelists of the nineteenth century failed to engage with. Woolf observed - in a lecture given to the Cambridge Heretics Society in May 1924 - that: "no generation since the world began has known quite so much about character as our generation". Woolf's fiction tends to be psychological, for she experiments with the working of the psyche of her characters and the permanence of the past in the present beyond the reach of realism. Her fiction treats the complex networks of emotions and memories of which the character is the center of the narrative. This paper accordingly, addresses the philosophical background of the Stream of Consciousness and its use within fictional exertion and how the latter is deployed in Woolf's Mrs. Dalloway (1925) to show and uncover the anxieties vis-à-vis her thanatophobia, not only this, but also to express the anxieties of the Great War and the disillusionment towards the modern enterprise.
\end{abstract}

Keywords: Henri Bergson, interior monologue, modernist fiction, Mrs. Dalloway (1925), stream of consciousness, Virginia Woolf, William James

Cites as: LARBI, N. (2019). A Literary Voyage into the Unconscious: A Philosophical Approach to the Psychological Novel in Woolf's Mrs. Dalloway (1925). Arab World English Journal for Translation \& Literary Studies, 3 (3) 178-187.

DOI: http://dx.doi.org/10.24093/awejtls/vol3no3.14 